Journal of Educational Method and Technology Vol. 1 No. 2, September 2018

P-ISSN 2622-8459 E-ISSN 2622-8467

http://ejournal.unima.ac.id/index.php/jemtec

\title{
Struggles in Cultural Construction by Ethnic Groups in the USA
}

\author{
I S Lolowang 1 \\ ${ }^{1}$ Universitas Negeri Manado, Indonesia \\ corresponding author: 1 imeldalolowan@unima.ac.id
}

\begin{abstract}
This article discusses about the struggles in cultural construction by some ethnic groups. These groups are attributed to their race and class as well. Through blending and negotiation experiences, the ethnic groups struggle to invent their identity and power in facing the dominant culture, the white people. They have to face both the external and the internal factors of their coexistence in the society. The groups discussed are the Mexican-American or the brown people, the African-American or the black, and the Asian-American or the yellow one.
\end{abstract}

Keywords: cultural construction, Mexican-American, AfricanAmerican, Asian-American, color people

\section{Introduction}

The world, nowadays, is a multi-cultural place. Many countries have experiences changes in their physical borders through times. Political, ideological as well as social changes have taken place. People keep moving from one place to another due to wars, economic reasons, as well as making their dreams come true. The United States has been the destination of immigrants to find peace, safety, and better life. It cannot be denied that the USA has been the place of a melting pot for races and ethnics.

The consequence of being a melting pot is that the USA has been a world laboratory to experiment with important issues of race, ethnicity, and class. This experiment is not as smooth as the representation of multiple races or colors of people in American movies or fiction nowadays. While American fiction and movies can show a good example for the rest of the world about how to get along among differences in the society by trying to represent all colors in them, this leading country has been going through very difficult time and scars of racial, ethnic, and class conflicts. However, through this example, the world can come to an understanding about the continuing efforts of the American spirit to work on such conflicts that seemingly never stop happening in USA itself, as well as in the parts of the world. Understanding these American issues is also understanding their life stories, narratives -whether fiction or non-fiction, as well as the world experiences, since this American experience has been involving the races and ethnics from all over the world that come to the country, by force or by freedom, by dreams or nightmares. 
The races, ethnicities, and classes in the US refer the real cultural experiences as well as the cultural constructions of identity and power within the country. American cultural groups blend and negotiate their interests with the broader dominant culture as well as with their own internal factors of origins that contain their deep cultural values and practices. Externally, the factors the groups have to deal with are for example, prejudice and discrimination. Internally, on the other hand, the factors they have to struggle with are beliefs and practices.

Although the nature of this topic may seems complex, it has a practical overview and lessons on the experience of pluralism in cultural construction process that can be a useful reference to understand American fact and fiction, as well as readers' own real experiences dealing with similarities and differences in the social life. The writer takes some examples of group blending strategies of negotiation from the experiences of the brown people or the Mexican-American, the black or the African-American, and the yellow or the Asian, in this case, the Chinese people in constructing their cultural identities in the cultural domination of the white people.

\section{Discussion}

Since there were more segregating efforts in public institutions like schools, for instance, than the other way around, the degree of blending became almost impossible for the early interaction among the white, black, and brown men or Hispanics in Texas cotton culture. According to Foley, this attitude of segregation mostly came from the dominant culture, with the main obstacle as the white racial superiority, that had also sustained the poverty of the non-white (116). The blending effort of the brown people remained difficult, since they focused on the goal of land ownership, which was the standard of identity of race, ethnic and power in that time. Their powerlessness was also kept by the institution of the federal government that favored the white landowners in its decision-making, including land-buying and citizenship (19).

The Mexican-American in California, on the other hand, soon found their power identity through the world of consumerism. The consumptive and cashoriented culture, thanks to the challenge of the Protestant work ethic and secularism, helped the brown people see their bargaining power as customers as well as laborers that had a voice. When they saw themselves as laborers, not as prospective land-owners, a more realistic self-perception than the Texans, soon they were aware of the importance of their involvement in politics to better their income and status, and to strengthen their identity within the industrial country. This phenomenon confirms Sanchez's statement that ethnicity was not a fixed set of customs surviving from life in Mexico, but rather a collective identity that emerged from daily experience in the United States (11). Furthermore, in quoting Octavio Paz, Sanchez states that "mexicanism floats in the air, because it never mixes or unites with the other world" (271).

Apparently, living between the two great poles of Americanization and Mexican nationalism makes the Mexican-Americans invented their own identity. Some Mexican-Americans adapted to Protestantism, but many others practiced "folk Catholicism" due to the inability of Catholic Church to provide enough 
facilities. These are some of the ways the Mexicans to maintain their own culture and values amid the doubt and prejudice of the dominant culture on their capabilities as humans. In addition, the ethno-religious organizations at church that saw the need to keep Mexicans in its workings had also helped invent their new identity as Mexican-Americans (166-167). The marketing services, however started to aim their promotion to the Mexican-American using Spanish, creating a special segment identity for these immigrants and reconnecting the people with their own Mexican root and past agrarian ideals. As the movies in English helped emerge the English-speaking second generation the younger Mexican-American generation, they were able to blend more with the dominant culture than the old generation. Now the language barrier was overcome more by the English language exposure through schools and media.

From time to time, the Mexicans learned to live with the political contradiction of the two countries and to balance their nationalistic sentiments with new identity. Whenever they fell into fierce trouble like the Depression, they always turned into their family and charity. The barrio has a special strength to shelter these people from hardships. This is how they amazingly construct their racial identity. The family and communal life proved to be the evident of the haven while strategizing reaction and attitude towards the dominant culture (Sanchez 11).

The Black culture in Levine's book constructed their class and power by using their artistic talents as a ritual for self-expression, due to their inability to "speak" in the larger society, developed that art, and gradually gained a new consciousness as individual. In their limited mobility and expression, the black used songs as emotional outlet to minimize the power of the dominant culture around them. They had work songs to concentrate their mind and physical movement and to criticize the white people around without being explicit. They used laughter as a compensating mechanism enabling them to confront oppression and hardship (Levine 299).

In the process of constructing a new racial identity, their songs and music became more personalized through cumulative changes spread over an extensive time, allowing gradual admixture of various styles and influence, without entirely discarding their communal aspect. As their secular song became more important in freedom, the sacred aspect of it was not shattered at all, but continued with different degree of pervasiveness (191). As the mechanization in post World War II gave more leisure time in working condition, the communal context of their song faded into the background, replaced by image of an isolated individual with a guitar, singing the blues (217), which was highly personalized and "inwardlooking". It was no coincidence that the emphasis of this individual expression was taking hold in Black song at the very time Booker T. Washington's philosophy and the notion of man's progress and destiny popularized by schoolteachers, white politicians, preachers, businessman, and "leaders" of every sort (223). However, Blues was still similar to the other types of Afro-American music. It still took materials from the folk, remained communal property, and taken and sung by others. Similarly, the development of Black hero in folk tales was becoming more conscious in the individual heroism as the center of the tales. 
However, as Jack Johnson defeated Burns in a wrestling championship, he stated that his personal triumph and honor was also the honor of his race (431). There has been always a communal consciousness accompanying the raise of Black individual consciousness, forming their racial identity; which would enable them to compete with the dominant culture without losing their communal heritage.

With their secretive practices, the degree of blending in their laughter with the dominant culture was carried out with a minimized conflict. Instead of laughing at somebody, the Black laughter tried to create a situation where they could laugh with him to avoid attackers (345). They were also very secretive in using their folklore since they used it as a tool for teaching reticence and caution (101). Their use of veiled sexual metaphors showed the double meaning of their message, which was also a kind of survival mechanism while expressing themselves (242). As they always tried to protect themselves in many ways while expressing themselves, the Black was always in defense of themselves in the fierce discrimination and prejudice around them.

Thanks to the genius of the art and creation of amazing music genres unknown before in American dominant culture, the music was becoming increasingly popular and now widely accepted among the White; not to mention now contributing an identity to American culture at large. However, the Black did not give up their cultural identity. As symbolized by Malcolm X, who straightened his hair, but kept his cultural independence in other areas (291). Therefore, the Black seemed to blend, in terms of being appreciated, successfully with the dominant culture without any fear of sacrificing their original values and practices due to a good defense and artistic charm.

Among the Catholic immigrant women in the mixed neighborhood in South Chicago in 1920s, there emerged two subcultures of immigrant women, the first and the second generations. The second generation was blended pretty well with the dominant culture through inter-ethnic church meeting, inter-ethnic marriages by choice and through the work field adaptation. Since the international conflict rose after the First World War, the immigrant families were stuck in the US, creating English-speaking sons and daughters claiming American citizenship as birthright (Orsi 1998:12). On the other hand, the daughters' longer stay in school due to the immigrant's tradition of sending the sons early to work, the young immigrant women with skill and education could adapt well in the post industrial economy and became more independent financially and personally (41).

It was a very difficult time for the first generation of Catholic women to deal with their daughters. The mothers wanted the daughters to marry inside the cultural or ethnic circle to preserve the strong family tradition and kinship brought a long way from Eastern and Southern Europe. The old tradition of submission, obedience, and dedication among family members and generations was threatened by the freedom their daughters adapted from the larger ethnic culture, which was apparently not too difficult to be absorbed among the white ethnics. In dealing with the situation above and other problems like illness and unemployment also burdened this first generation of immigrant women.

On the other hand, the life of the second generation immigrant women was not all easy. The choice they made and the independence they had put them in a 
great pressure between the old world of the parents and the new world of their own. The young women's responsibilities were more intense than the young males. The young women were situated at the center of family conflict, responsible for looking after the kin left behind in the old neighborhood they had been avoiding after marriage, and the fiercely contested domains of work and love, including the distress of childbearing years in the modern nuclear family (40). As modern women, they wanted equal and mutually supportive relations with their husbands, but unfortunately, the husbands were less modern in their marital values that the women often had to seek annulment on grounds of cruelty and abuse (42).

The condition of both generations brought them together on the same page of life problems and burdens. For the second generation especially, they had to negotiate between the image of what they should be and desire as dictated by family or culture, and their own hopes of what they might become (44). As Saint Jude became popular with his healing miracle to a person with a near-death experience, the Catholic immigrant women made him as their patron saint of hopeless causes. Besides asking for healing and problem solutions, the devotion to saint was also a kind of way of honoring the family or parents separated now by inter-ethnic marriages. The devotion to the saint encouraged by successful stories of prayers answered was the source of power for the immigrant women to deal with the challenges of their transition period from the old world to the new one.

The second generation's potential to blend put them on the relatively similar work position and modern marriage problems like the women from the dominant culture.

However, the obligation to the parental family and fear of not being able to fulfill it, together with the different perception between them and their husbands in family matters were fierce challenges for their newly found independence and dream. On the other hand, the dream gained of the second generation was a totally nightmare for the first generation who lost their control and honor, and probably financial support, which were the elements of their traditional culture now began to uproot

The cultural construction of the Chinese women in San Francisco in late 19 th century to early 20th century focused on the empowerment of the Chinese women, who were victimized by the extreme subordination of women in Chinese culture and racial discrimination and treatment in white society (Yung 1995). Unable to resist the gender slavery under the traditional male authority, which initially sent them to America for the sole purpose of prostitution, the only help available was from the Christian missionaries who came to their rescue. The traditional Chinese culture totally expelled the Chinese women to the lowest rank in their family system, obliged to obey all three male generation for all her life and easily objectified especially in a fierce situation of Chinese males' discriminated life far from home, contrary to the ideas of freedom and individualism of their dominant white neighbors.

Due to some reasons, the saved Chinese women did not easily convert to Christianity or adopting Victorian values. Sticking to their own culture and combined their efforts with the freedom, self-image ideas of the missionaries, the 
Chinese women shaped a new set of gender relation in their Chinese-American arrangement. As more Chinese women came to America, exposed to Christianity and work fields, while still exposed to their male subordinating power at home, the Chinese women did not try to uproot themselves out of the Chinese culture. They used the Christian shelters as temporary refuge from male abuse and arranged marriage as well as to gain advantage in polygynous marriage. At home, they unbound their feet by developing a position as a helpmate for the husbands in the home economy in the new country. Other thing that held them back was the Chinese nationalist efforts to strengthen and defend China against further foreign encroachment.

Some Chinese women, especially the ex-prostitutes, adopted Christianity, showing that there was a certain degree of blending with the larger society. However, these women had to come home to their own bounding. Understanding the hard realities at home, which were the source of problem, the Chinese women decided to focus their reformation starting with empowering themselves morally, intellectually, physically, and socially (96). As they received examples from White and Black women reformers, they invented their own women's reformation group adapting the self-reliant spirit from the dominant culture (92).

With the language and traditional barriers, the blending of the Chinese women with the dominant culture were not easy, due to the widely held negative opinion on Chinese women as reared to a life of shame from infancy and accused of disseminating vile diseases capable of destroying morals, manhood, health, and nations (32). With the impossibility of getting help from their male counterpart and the difficulty in finding leisure time for organizational matters, the only initial positive cultural bridge that they used so efficiently was the Christian missionary reach out that transferred their values and shared the common needs of the women. During the darkest years of Jim Crow, the Black women in North Carolina emerged to win their right to voting, by the time Black men lost their political rights, 'paralyzed' by well-crafted fear of black rapists of white women (Gilmore 1996). They constructed their power by filling up the opening they found in the political administration, which promoted community betterment in education, health, and welfare work (147). With this new public role, the black women took civic actions, becoming spokespersons and motivators, connecting with cross-denominational, later, party lines (148). When white women lobbied to obtain services from their men, black women lobbied to obtain services for their 'paralyzed' men (149).

Both women used church organizations for social conditions improvement as their parapolitical tool, to condemn the whites' rapist accusation towards black males, and be a client for or interpreter for families' social needs (151). As they moved toward creating better homes for the families, black women saw the needs of education for the women, especially literacy, which had a political significance, since voting required literacy (112). With the invisible interdenominational link of women's religious clubs, the white women gained confidence on the black women's management and reliability, first hand, raising a question on the crafted lies spread by white men in the male model of relations 172). 
The right moment finally came for the black women to make their appeals to the white women to help them end lynching and mob violence towards black men, to establish a home for delinquent African-American girls, and, the most important thing was, to obtain the right of the Negro women to share equally the franchise to vote which would soon be granted to the state womanhood (200). With a humble, reasonable personal negotiation, Charlotte Brown asked the white women not to "crush the black women under their feet while reaching out for the same hand'. In other words, the black women asked the white women to use their access to white [men's] supremacy to ask for a right to vote without ignoring the same needs of the black women (201). When convinced that the white women would outnumbered the black women in voting, white men allowed both women groups to vote, with the victory of the women at the end (224). Although black women had been living with full awareness of the problem of racism and sexism, they could not end racism or sexism by themselves. Using the white women's help was proven a successful strategy in constructing their cultural power to vote, which would open more doors for their men and future. With the impossibility of black men's help, they used the only way available that time, the social service involvement -something they naturally always did-as their invisible path to freedom.

As the black best men thought that they were well recognizable by the white men if they conformed well to the white values, the best of the black women had won the heart of the white women through their cooperation religious organizations. However, the black in general had been adopting and using the general white cultural values like hard work, strong educational tradition, leadership, and manner to survive amid the darkest years of Jim Crow. That the black men were still proved unsuccessful due to the more obvious political threat felt by the white men, confirmed black's equal capabilities to those of the white's. The black women's efforts, however, went unnoticed since they chose to deal with womanly affairs of home betterment and such. Choosing their entrance path carefully and naturally, the black women soon found an outlet of their aspiration through their partnership with the white women who shared the common struggle for women suffrage, only that the white women had easier access to triumph.

In their long struggle for freedom, through cultural construction of identity, Americans had their own ways to reach triumph based on their beliefs rooted in their original culture or through the cultural suffering and disaster. Each group or subculture had their own agenda to fight for and levels of cultural achievement won or lost. With their own degree of adaptation to the dominant culture, they constructed their own identity or power. As America is filled with different ethnic struggles, the dominant white culture itself seemed to be excluded from this term ethnic. To be ethnical seems to mean to be other than white, denying the facts that other whites also struggled just like the non-whites (285). As they struggled, it happens not without resistance, challenging the assumption so receptive to the notion of "melting pot" (287).

\section{Conclusion}


It can be concluded that, in social life, there is no free or lazy seasons for ethnic groups in establishing their own identity within a larger society, especially in the face of a dominant culture. Different ethnics may have the same as well as different problems and strategies in inventing and safeguarding their identity and power. They may coexist in the same country, but they surely have different struggles to fight on.

The Mexican-American group invented their identity placing themselves as powerful consumers in the industrial society. The African-American group used their artistic talents especially in music in finding their niche within the larger society, constructing their consciousness on their power identity. The AsianAmerican group struggled for their power identity through the empowerment of their women, who suffered most compared to their male gender group. Sometimes women might be more successful in negotiating their blending efforts with the dominant culture, due to their 'invisibility' in the society, compared to the easily recognized and easily paralyzed efforts by the males.

It can be understood that struggles for identity and power within the context of cultural construction are continuing efforts. Ethnic groups always need to identify and reidentify themselves to keep their existence and coexistence at peace. This cultural experience can be a useful lesson for the world to learn about pluralism and to understand a culture in a deeper way than just believing the sometimes unreal images of America in movies, narratives, or advertisement representation.

\section{References}

Foley, Neil. The White Scourge: Mexicans, Blacks, and Poor Whites in Texas Cotton Culture. Berkeley: University of California Press, 1999.

Gilmore, Glenda. Gender and Jim Crow: Women and the Politics of White Supremacy in North Carolina, 1896-1920. Chapel Hill: University of North Carolina Press, 1996.

Levine, Lawrence W. Black Culture and Black Consciousness: Afro-American Folk Thought from Slavery to Freedom. New York: Oxford University Press, 1978.

Orsi, Robert A. Thank You, St. Jude: Women's Devotion to the Patron Saint of Hopeless Causes. Binghamton, New York: Vail-Ballou Press, 1998.

Sanchez, George J. Becoming Mexican American: Ethnicity, Culture, and Identity in Chicano Los Angeles, 1900-1945. Oxford: Oxford University Press, 1995.

Yung, Judy. Unbound Feet: A Social History of Chinese Women in San Francisco. Berkeley: University of California Press, 1995. 